\title{
PHYSICAL SOIL ATTRIBUTES IN DIFFERENT EUCALYPTUS CROP MANAGEMENT SYSTEMS IN WESTERN MATO GROSSO, BRAZIL
}

\author{
Elyson Thiago de Souza Florentim ${ }^{1}$, Helen Caroline Rodrigues Correa², Paloma Emanuela Braga Martins ${ }^{3}$, \\ Fulvianny Cristina da Silva ${ }^{4}$, Walmes Marques Zaviani ${ }^{5}$, Milson Evaldo Serafim ${ }^{6 *}$ \\ ${ }^{1}$ Instituto Federal de Educação, Ciência e Tecnologia de Mato Grosso - Campus Cáceres - Prof. Olegário Baldo, Cáceres, Brasil, \\ thiagoflorentim28@gmail.com; ${ }^{2}$ helen.correa05@gmail.com; ${ }^{3}$ palomabraga07@gmail.com; ${ }^{4}$ fuviakris@gmail.com; \\ ${ }^{* 6}$ milson.serafim@cas.ifmt.edu.br; \\ ${ }^{5}$ Universidade Federal do Paraná, Departamento de Estatística, Paraná, Brasil, walmeszeviani@gmail.com.
}

Received for publication: 17/01/2018 - Accepted for publication: 29/06/2020

\begin{abstract}
Resumo
Atributos físicos do solo sob diferentes manejos para a eucaliptocultura na região oeste de Mato Grosso, Brasil. O objetivo deste trabalho foi determinar o efeito de quatro sistemas de manejo do solo sobre os atributos físicos de um Latossolo, para plantação de Eucalyptus localizado na região Oeste do Estado de Mato Grosso, Brasil. Os sistemas de manejo se diferenciam pela forma de preparo do solo nas fases de implantação e estabelecimento inicial da floresta, sendo um sistema convencional (aração, gradagem e subsolagem no preparo e no pós-plantio gradagem para o controle do mato) e um sistema conservacionista (dessecação da pastagem, subsolagem, controle do mato com herbicida e cultura de cobertura), acrescentando diferenças pela forma de fornecimento da adubação para o eucalipto (a lanço e no sulco). Em cada sistema de manejo foram amostradas nove camadas do solo de forma contínua na entre linha de plantio, utilizando anéis volumétricos de $100 \mathrm{~cm}^{3}$ (diâmetro e altura de $0,05 \mathrm{~m}$ ) totalizando uma camada estudada de $0,45 \mathrm{~m}$. Foram avaliadas as variáveis: volume total de poros, microporosidade, macroporosidade, densidade e resistência do solo à penetração. Os diferentes manejos não promoveram diferenças significativas para os atributos estudados dois anos após a implantação da floresta, sendo observado apenas pequeno efeito da profundidade. Os valores encontrados para os atributos estão dentro de limites adequados para o desenvolvimento da cultura de Eucalyptus, indicando boa qualidade do solo sob floresta de eucalipto para as condições do estudo.

Palavras chave: Cultura de cobertura, Eucalyptus, manejo do solo, resistência do solo à penetração.
\end{abstract}

\begin{abstract}
The aim of this study was to determine the effect of four soil management systems on the physical attributes of an Oxisol for Eucalyptus crops in western Mato Grosso, Brazil. The management systems are differentiated by the soil preparation form during the implantation and initial forest establishment phases, namely a conventional system (plowing, harrowing and subsoiling for preparation and harrows for weed control after planting ) and a conservationist system (pasture desiccation, subsoiling, herbicide weed control and cover crop), with added differences in the eucalyptus fertilizer supply manner (haul and furrow). Nine soil layers were sampled continuously for each management system in between the sowing lines using $100 \mathrm{~cm}^{3}$ volumetric rings $(0.05 \mathrm{~m}$ in diameter and height), totaling a studied layer of $0.45 \mathrm{~m}$. The following variables were evaluated: total pore volume, microporosity, macroporosity, density and soil resistance to penetration. The different managements did not lead to significant differences for the studied attributes two years after forest establishment, with only a small depth effect observed. The attribute values are within the appropriate limits for eucalyptus crop development, indicating good soil quality under the eucalyptus forest for the study conditions.

Keywords: Cover crop, Eucalyptus, soil management, soil penetration resistance.
\end{abstract}

\section{INTRODUCTION}

The Brazilian forestry sector is based on the Eucalyptus genus, which occupies 5.7 million hectares of the total 7.83 million forest hectares present in the country (INDÚSTRIA BRASILEIRA DE ÁRVORES - IBÁ, 2019). The expansion of Eucalyptus forests in Brazil is due to the wide adaptability of this species to the most diverse edaphoclimatic conditions (FERREIRA et al., 2017).

In the state of Mato Grosso, eucalyptus crops are still incipient, and little information is available concerning eucalyptus-responsive management practices, unlike in other Brazilian regions, which already apply genotype-specific

FLORESTA, Curitiba, PR, v. 50, n. 4, p. 1679 - 1688, out/dez 2020.

Florentim, E. T. S. et.al.

ISSN eletrônico 1982-4688

DOI: 10.5380/rf.v50 i4. 57466 
management systems. As a rule, eucalyptus genotypes strongly interact with their environment, and chemical, physical and biological factors are prominent (SANTOS et al., 2015).

Physical soil attributes are directly associated to water availability, as they are responsible for defining soil water storage capacity and root growth conditions along the soil profile (BAPTISTA; LEVIEN, 2010). In a broader context, physical soil quality, which is determined by soil structure, both directly and indirectly alters plant production and environmental quality (WENDLING et al., 2012). Soil structure is associated to soil density, porosity, permeability, soil resistance to root penetration, and water availability, among others (SILVA et al., 2011).

The municipality of Cáceres, in western Mato Grosso, exhibits marked edaphological drought characteristics, stimulated by the high temperatures and low precipitation levels occurring during certain periods of the year (NEVES, 2011). Because of this, management practices that favor deep root growth are paramount. Decreased soil resistance to penetration through subsoiling practices in eucalyptus sowing furrows favors plant root system development, which can then begin to explore larger soil volumes, increasing water and nutrient absorption. Thus, adequate fertilization management practices favor root growth and development, resulting in larger areas to be explored, containing higher organic material concentrations which directly influence structural soil quality, permitting increased particle aggregation and, consequently, improved aggregate stability (BORDRON et al., 2019; GHOSH et al., 2019)

The adoption of a conservation system for eucalyptus crops aiming to improve soil water storage conditions and promote root growth are valid alternatives to mitigate crop water deficits. In this context, the aim of the present study was to evaluate physical soil attributes, porosity, density and soil penetration resistance in two different eucalyptus crop management systems established in Cáceres, Mato Grosso, Brazil.

\section{MATERIAL AND METHODS}

The present study was conducted at the IFMT experimental farm, Cáceres Campus, located in the municipality of Cáceres, MT. The local climate according to the Köppen classification is hot and humid tropical, with a dry winter (Awa) (NEVES, 2011). The soil is classified as a Dystrophic Red Latosol, with a clay content of $230 \mathrm{~g} \mathrm{~kg}^{-1}$ and displaying a slight depth gradient.

The experimental eucalyptus area occupies 2 ha and was established on an area previously occupied for 14 years by a Uroclhoa brizantha pasture. The area was in use until the beginning of the eucalyptus forest sowing preparation operations, with an average capacity of 3.5 animal units (450 kg live weight). Grass suppression was performed 45 days before eucalyptus planting, by applying glyphosate at a dose of $2.5 \mathrm{~kg} \mathrm{ha}^{-1}$ (glyphosate ammonium concentration $=792.5 \mathrm{~g} \mathrm{~kg}^{-1}$ ). A second application of the same herbicide was performed 12 days before eucalyptus planting, at $1 \mathrm{~kg} \mathrm{ha}^{-1}$. Another herbicide application was carried out on the crop planting lines to control signalgrass, one day before eucalyptus planting, using a paraquat + diuron mixture at $2 \mathrm{~L} \mathrm{ha}^{-1}$ (190g L $\mathrm{L}^{-1}$ of active ingredient), applied by a directed spray applied at $0.75 \mathrm{~m}$ on each side of the planting furrows.

Soil management and sampling depths were assessed for four management system levels (Table 1) and nine depth levels. The cover crop treatments consisted of signalgrass (Urochloa ruziziensis).

Tabela 1. Níveis de manejo do solo para cultura do Eucalyptus adotados neste estudo.

Table 1. Soil management levels for the Eucalyptus cultivation adopted in the present study.

\begin{tabular}{|c|c|c|c|c|}
\hline Treatment & System & Cover crop & Crop fertilization & Cover fertilization \\
\hline $1(\mathrm{~S})$ & Conventional $^{1}$ & Absent & Furrow & Line \\
\hline 2 (BS) & Conservationist $^{2}$ & Signalgrass & Furrow & Line \\
\hline $3(\mathrm{BL})$ & Conservationist & Signalgrass & Haul & Furrow \\
\hline 4 (BSL) & Conservationist & Signalgrass & $1 / 2$ furrow $+1 / 2$ Haul & $1 / 2$ furrow $+1 / 2$ Haul \\
\hline
\end{tabular}

Conventional soil preparation was performed through initial layer plowing up to $0.2 \mathrm{~m}$, using a plowing harrow with 32-inch discs, followed by two leveling harrow passes. Subsoiling was then carried out with a fertilizer subsoiler, equipped with a straight-inclined rod without wings, at a depth of $0.7 \mathrm{~m}$, including the other management systems. The soil was dry up to $0.3 \mathrm{~m}$ and friable during subsoiling, with humidity ranging between 0.22 and $0.27 \mathrm{~m}^{3}$ $\mathrm{m}^{-3}$ from 0.30 to $0.50 \mathrm{~m}$.

FLORESTA, Curitiba, PR, v. 50, n. 4, p. 1679 - 1688, out/dez 2020

Florentim, E. T. S. et.al.

ISSN eletrônico 1982-4688

1680

DOI: $10.5380 /$ rf.v50 i4. 57466 
Crop fertilization was carried out with $400 \mathrm{~kg} \mathrm{ha}^{-1}$ of a $06-30-06+1 \% \mathrm{Zn}+1 \%$ B formula, and cover fertilization was performed with $400 \mathrm{~kg} \mathrm{ha}^{-1}$ of a 20-00-20 mix, comprising three moments, with the first cover fertilization carried out at the beginning of the following rainy season (October), by hauling the total area. Fertilization and liming recommendations were defined according to Neves et al. (2008), based on a previous soil analysis.

Furrow fertilization treatments were carried out before sowing, with fertilizer distribution adjusted for maintenance at a depth of $0.35 \mathrm{~m}$ during subsoiling operations. Regarding the haul fertilization treatments, the fertilizer was distributed throughout the total area after signalgrass establishment in the conservationist treatments, 25 days after seedling sowing.

The VM 01 (Eucalyptus urophylla x Eucalyptus camaldulensis) clone was used, spaced 3 x $2 \mathrm{~m}$ and sowed on the first and second days of May 2014. Ten days after planting, signalgrass was sowed by hauling throughout the total area. Subsequently, a tree trunk was passed over the area to promote greater contact between the seeds and the soil.

The paraquat + diuron herbicide mixture was applied to the sowed lines at a $2 \mathrm{~L} \mathrm{ha}^{-1}$ dose $\left(190 \mathrm{~g} \mathrm{~L}^{-1}\right.$ of active ingredient) to control invasive plants after sowing, using a directed jet between sowed lines. A tractor brush cutter was used in the signalgrass treatments (BS, BL, BSL), while a light harrow was used in the signalgrass-free treatment (S).

A randomized block (RBC) experimental design consisting of four treatments and six replications was applied, totaling 24 plots comprising 136 plants per plot. All evaluations were carried out 2 years after the eucalyptus forest establishment.

In order to preserve the soil structure during sampling, trenches were opened up in each plot and samples were collected using $100 \mathrm{~cm}^{3}$ volumetric rings ( $0.05 \mathrm{~m}$ in height and diameter), at the following soil layers: 0.00-0.05; $0.5-0.10 ; 0.10-0.15 ; 0.15-0.20 ; 0.20-0.25 ; 0.25-0.30 ; 0.30-0.35 ; 0.35-0.40$ and $0.40-0.45 \mathrm{~m}$, totaling nine undisturbed samples per plot. The samples were obtained from the center of the sowed lines, in order to isolate effects regarding the presence or absence of signalgrass, as well as any furrow or haul signalgrass fertilization effects.

To determine sample water content at saturation under $6 \mathrm{kPa}$, the soil samples were saturated by capillarity and their masses were determined. The samples were then subjected to a $6 \mathrm{kPa}$ tension using a porous plate funnel. Total pore volume (VTP) was given by the water content in the saturation moisture. Microporosity is defined as the water content under a $6 \mathrm{kPa}$ tension. Macroporosity was determined by the difference between the VTP values and microporosity (TEIXEIRA et al., 2017).

After reaching equilibrium at $6 \mathrm{kPa}$, soil mass and resistance to penetration were determined. Resistance to penetration was obtained using a bench-top electronic penetrometer, equipped with a $45^{\circ}$ and $4 \mathrm{~mm}$ diameter circular cone tip, with rod displacement set at a constant speed of $2 \mathrm{~mm} \mathrm{sec}^{-1}$ with $50 \mathrm{~mm}$ penetration. The mean penetration resistance value was calculated for each sample, disregarding the first and last 25 readings referring to the initial and final $5 \mathrm{~mm}$ of each sample.

After determining soil resistance to penetration, the samples were dried in an oven at $105^{\circ} \mathrm{C}$ for $48 \mathrm{~h}$ in order to calculate dry soil masses and densities (TEIXEIRA et al., 2017).

The statistical data analyses including soil depth as an additional factor assumed a subdivided plot model with a completely crossed factor structure, given by:

$$
y i j k=\mu+\mathrm{BLC} i+\mathrm{MAN} j+s(\mathrm{PROF} k)+\mathrm{MAN} j \cdot s(\mathrm{PROF} k)+u i j+e i j k
$$

Where:

- yijk is the observed value for the response in a plot in block $i$ with management $j$ at depth $k$;

- $\mu$ is a constant belonging to all observations that, only in the absence of effects from the other terms in the model, corresponds to the separate value of the response;

- BLC $i$ represents the effect of the blocks $(i=1, \ldots, 6)$, assumed as random effect;

- MAN $j$ represents the main management effect $(j=1, \ldots, 4)$;

- $s$ (PROF $k$ ) represents the effect of depth $(k=1, \ldots, 9)$. As depth is a quantitative factor, a base function is used to represent its effect, of a cubic spline (3 degrees of freedom);

- MAN $j \cdot s(\mathrm{PROF} k)$ represents the interaction between management and depth.

- uij is the experimental error at the plot level, which is assumed to be independent and display a mean distribution of 0 and constant variance.

- eijk is the experimental error at the soil sample level, which is assumed to be independent and display a mean distribution of 0 and constant variance.

FLORESTA, Curitiba, PR, v. 50, n. 4, p. 1679 - 1688, out/dez 2020.

Florentim, E. T. S. et.al.

ISSN eletrônico 1982-4688 
The assumption of error independence along the profile at a given collection position may not be verified, given that nearby soil samples may show spatial dependence. Therefore, an exponential correlation structure was initially considered for sample level error:

$$
\mathrm{p}(\mathrm{d})=\exp \left\{\frac{-d}{\lambda}\right\}
$$

where $d$ is the difference in depths and $\boldsymbol{\lambda}$ is the parameter related to the extent of spatial dependence

In practice, the range is the distance at which the correlation is of $5 \%$ which corresponds to $d=3 p \approx 0.05$. In the absence of spatial dependence, the simplest model of independent errors is considered, i.e. $p=0$.

Since the terms of the cubic spline base function were not significant, the linear model was adjusted to represent the depth effect, as:

$$
s(\operatorname{PROF} k)=\beta 0+\beta 1 \mathrm{PROF} k
$$

And with no interaction between management and depth, the additive model was adjusted to:

$$
y i j k=\mu+\mathrm{BLC} i+\mathrm{MAN} j+s(\mathrm{PROF} k)+u i j+e i j k
$$

The described models for the hypothesis tests concerning the effect of the experimental factors were adjusted to the data by the restricted maximum likelihood method (REML), while the maximum likelihood method (ML) was applied to test for spatial dependence. The statistical software R version 3.3.2 was used for the data analysis (2016-1031), using the nlme package (PINHEIRO et. al, 2019).

An adjusted curve was obtained to present the results, accompanied by the confidence bands for each regression $(95 \%)$, based on the final model.

\section{RESULTS}

Concerning the studied variables 2 years after the eucalyptus forest establishment, no significant effects for total pore volume, microporosity macroporosity regarding management source variations, layer and management:layer were observed. A significant effect was detected only for soil density and resistance to penetration in the spline bases (layer) variation sources and for the management:spline bases (layer) interaction (Table 2).

Tabela 2. Resumo da análise de variância para a variáveis resposta volume total de poros (VTP), microporosidade (Micro), macroporosidade (Macro), densidade do solo (Ds) e resistência do solo a penetração (RP) para os níveis de manejo e profundidades estudadas.

Table 2. Summary of the variance analysis for total pore volume (VTP), microporosity (Micro), macroporosity (Macro), soil bulk density (Ds) and soil penetration resistance (RP) for the studied management levels and depths.

\begin{tabular}{lccccccc}
\hline V.S. & g.l. Num $^{\mathbf{1}}$ & g.l. Den $^{\mathbf{3}}$ & F VTP $^{\mathbf{4}}$ & F Micro $^{\mathbf{5}}$ & F Macro $^{\mathbf{6}}$ & F Ds $^{\mathbf{7}}$ & RP $^{\mathbf{8}}$ \\
\hline Management & 3 & 15 & $0,266^{\mathrm{ns}}$ & $1,517^{\mathrm{ns}}$ & - & - & - \\
Layer & 1 & 187 & $0,272^{\mathrm{ns}}$ & $1,991^{\mathrm{ns}}$ & - & - & - \\
Management:Layer & 3 & 187 & $0,217^{\mathrm{ns}}$ & $1,673^{\mathrm{ns}}$ & - & - & - \\
& & & & & & & \\
Management & 3 & 15 & - & - & $0,713^{\mathrm{ns}}$ & $0,590^{\mathrm{ns}}$ & $0,379^{\mathrm{ns}}$ \\
Base spline (layer) & 3 & 180 & - & - & $0,973^{\mathrm{ns}}$ & $12,44^{* *}$ & $7,781^{* *}$ \\
Management:Base spline (layer) & 9 & 180 & - & - & $2,471^{\mathrm{ns}}$ & $2,47^{* *}$ & $2,551^{* *}$ \\
\hline
\end{tabular}

**, * and ${ }^{\mathrm{ns}}$ : significant at $1 \%$ and $5 \%$ probability and non-significant, respectively.

${ }^{1}$ F.V. variation source; ${ }^{2}$ g.1. Num.: Numerator degrees of freedom; ${ }^{3}$ g.1. Den.: denominator degrees of freedom; ${ }^{4,5,6,7,8}$ F value for VTP, Micro, Macro, Ds and RP.

Total porosity, given by water content at saturation (Figure 1), did not differ significantly between management and soil layer.

FLORESTA, Curitiba, PR, v. 50, n. 4, p. 1679 - 1688, out/dez 2020.

Florentim, E. T. S. et.al.

ISSN eletrônico 1982-4688

DOI: 10.5380/rf.v50 i4. 57466 


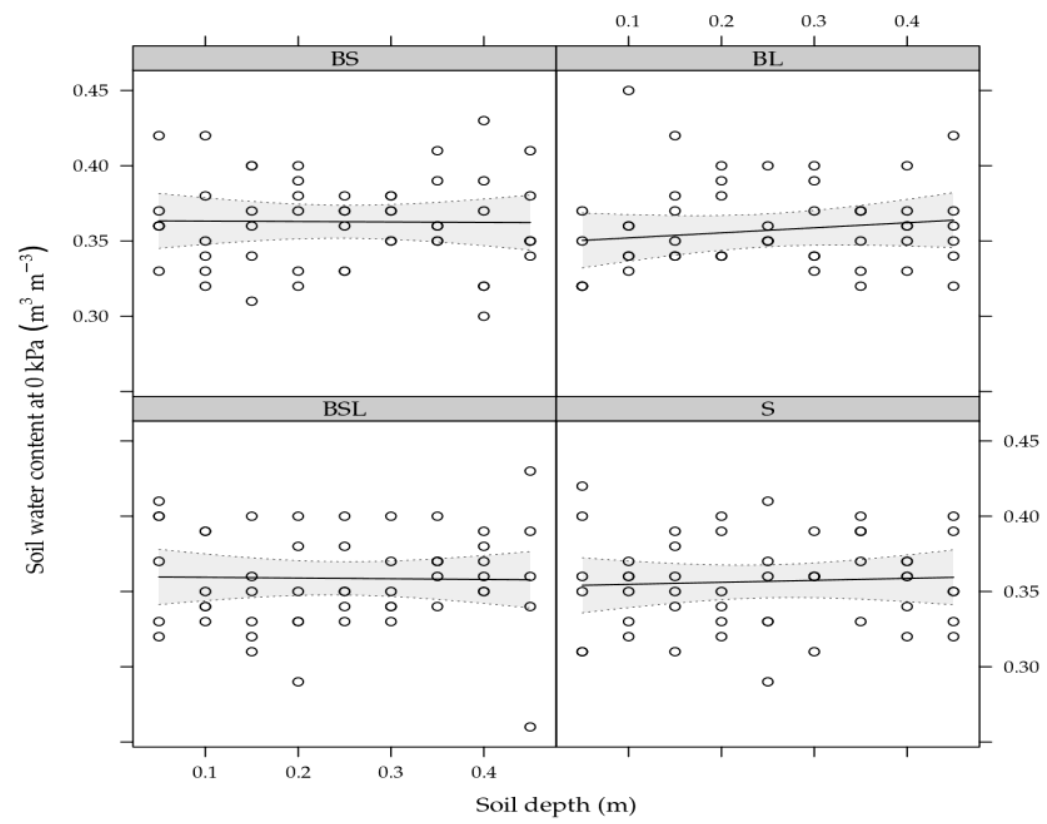

Figura 1. Conteúdo de água no solo à $0 \mathrm{kPa}\left(\mathrm{m}^{3} \mathrm{~m}^{-3}\right)$, correspondente ao volume total de poros, em função da profundidade (m), em cada nível de manejo do solo. A linha que expressa o ajuste do modelo está acompanhada das bandas de confiança $(95 \%)$.

Figure 1. Soil water content at $0 \mathrm{kPa}\left(\mathrm{m}^{3} \mathrm{~m}-3\right)$, corresponding to total pore volume, as a function of depth $(\mathrm{m})$, at each soil management level. The line that expresses the fit of the model is accompanied by the confidence bands $(95 \%)$.

Microporosity, given by water soil content at $6 \mathrm{kPa}$ (Figure 2), was not significantly different between the two types of studied management and layers. Higher microporosity, however, was observed for the BSL management, in the soil layer ranging from 0.35 to $0.45 \mathrm{~m}$.

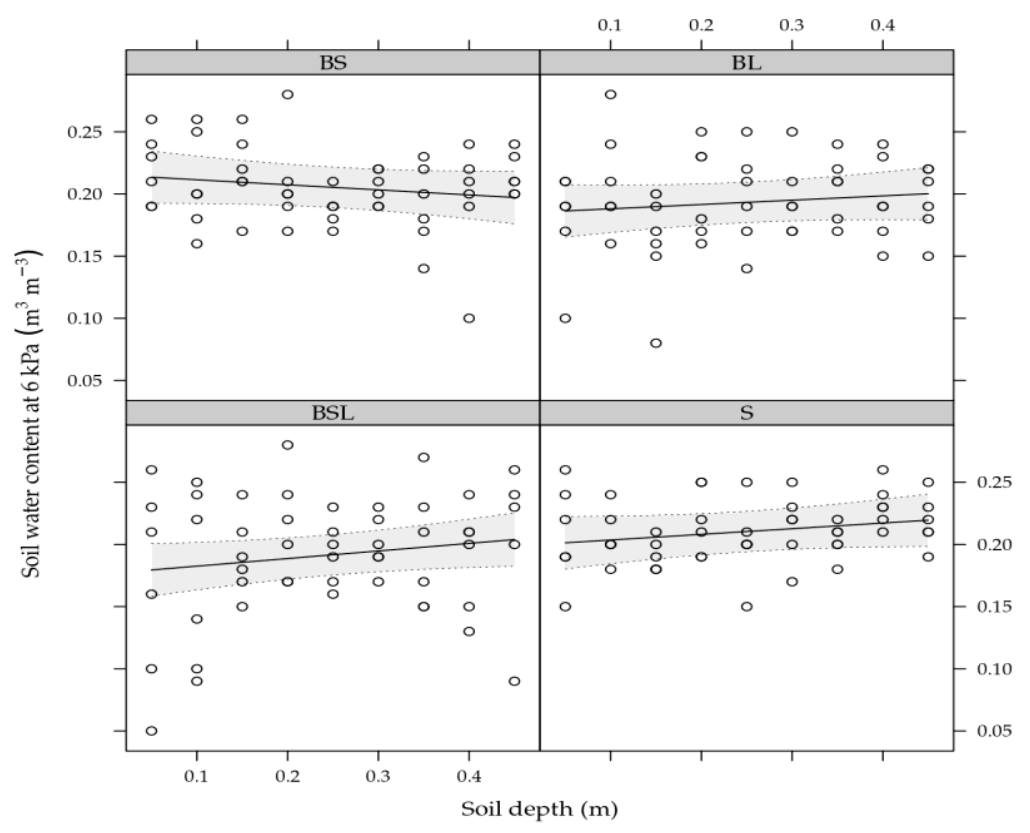

FLORESTA, Curitiba, PR, v. 50, n. 4, p. 1679 - 1688, out/dez 2020.

Florentim, E. T. S. et.al.

ISSN eletrônico 1982-4688

DOI: $10.5380 /$ rf.v50 i4. 57466 
Figura 2. Conteúdo de água no solo a $6 \mathrm{kPa}\left(\mathrm{m}^{3} \mathrm{~m}^{-3}\right)$, correspondente a microporosidade, em função da profundidade (m), em cada nível de manejo do solo. A linha que expressa o ajuste do modelo está acompanhada das bandas de confiança $(95 \%)$.

Figure 2. Soil water content at $6 \mathrm{kPa}\left(\mathrm{m}^{3} \mathrm{~m}^{-3}\right)$, corresponding to microporosity, as a function of depth $(\mathrm{m})$, at each soil management level. The line that expresses the fit of the model is accompanied by the confidence bands $(95 \%)$.

Macroporosity, given by the difference in soil water content between 0 and $6 \mathrm{kPa}$ (Figure 3), was statistically similar for both management and layer. The BSL management, again displaying no significant difference, exhibited the highest macroporosity in the 0.00-0.05 m layer and the lowest, between 0.40 and $0.45 \mathrm{~m}$.

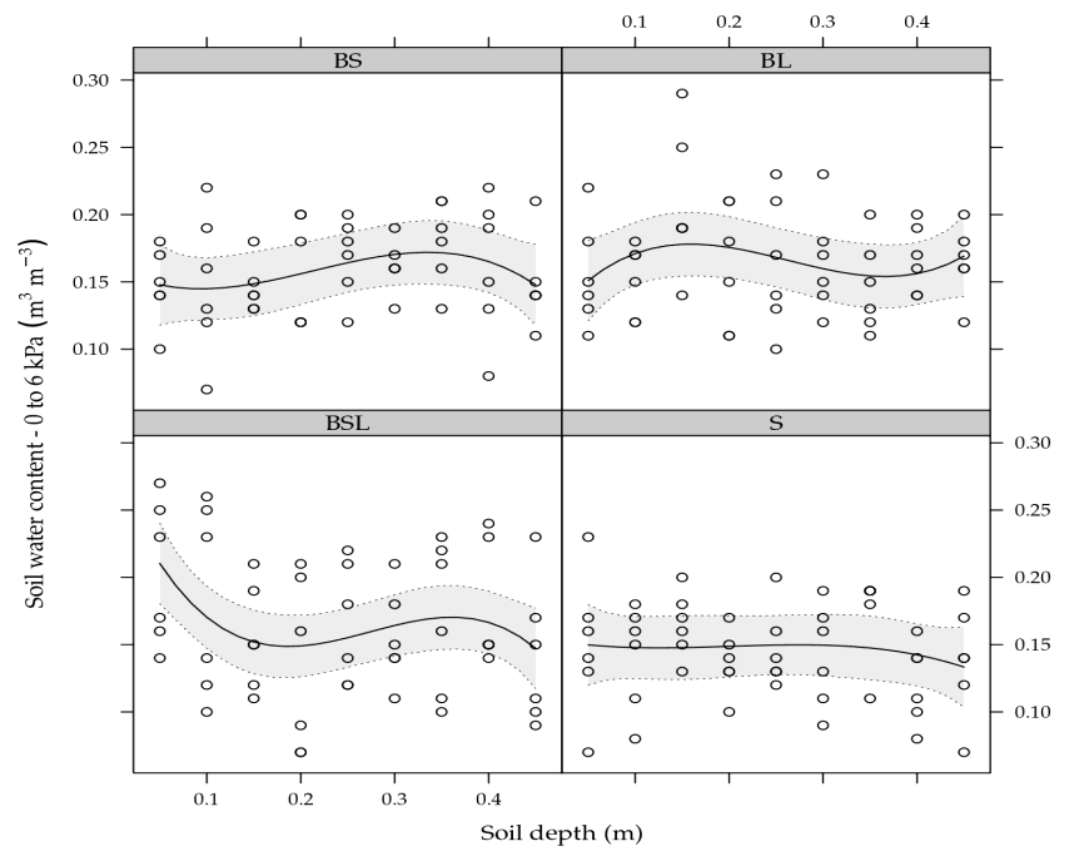

Figura 3. Conteúdo de água no solo - 0 a $6 \mathrm{kPa}\left(\mathrm{m}^{3} \mathrm{~m}^{-3}\right)$, correspondente a macroporosidade, em função da profundidade (m), em cada nível de manejo do solo. A linha que expressa o ajuste do modelo está acompanhada das bandas de confiança (95\%).

Figure 3. Water content in soil from 0 to $6 \mathrm{kPa}\left(\mathrm{m}^{3} \mathrm{~m}^{-3}\right)$, corresponding to macroporosity, as a function of depth (m), at each soil management level. The line that expresses the fit of the model is accompanied by the confidence bands (95\%).

No significant differences between mean soil density values per layer were noted for the BL, BS and $\mathrm{S}$ managements (Figure 4). In the BSL management, however, a significant layer effect was observed, with the lowest density of $1.49 \mathrm{Mg} \mathrm{m}^{-3}$ observed at a depth of $0.00-0.05 \mathrm{~m}$, and the highest, of $1.61 \mathrm{Mg} \mathrm{m}^{-3}$, at $0.15-0.20 \mathrm{~m}$. 


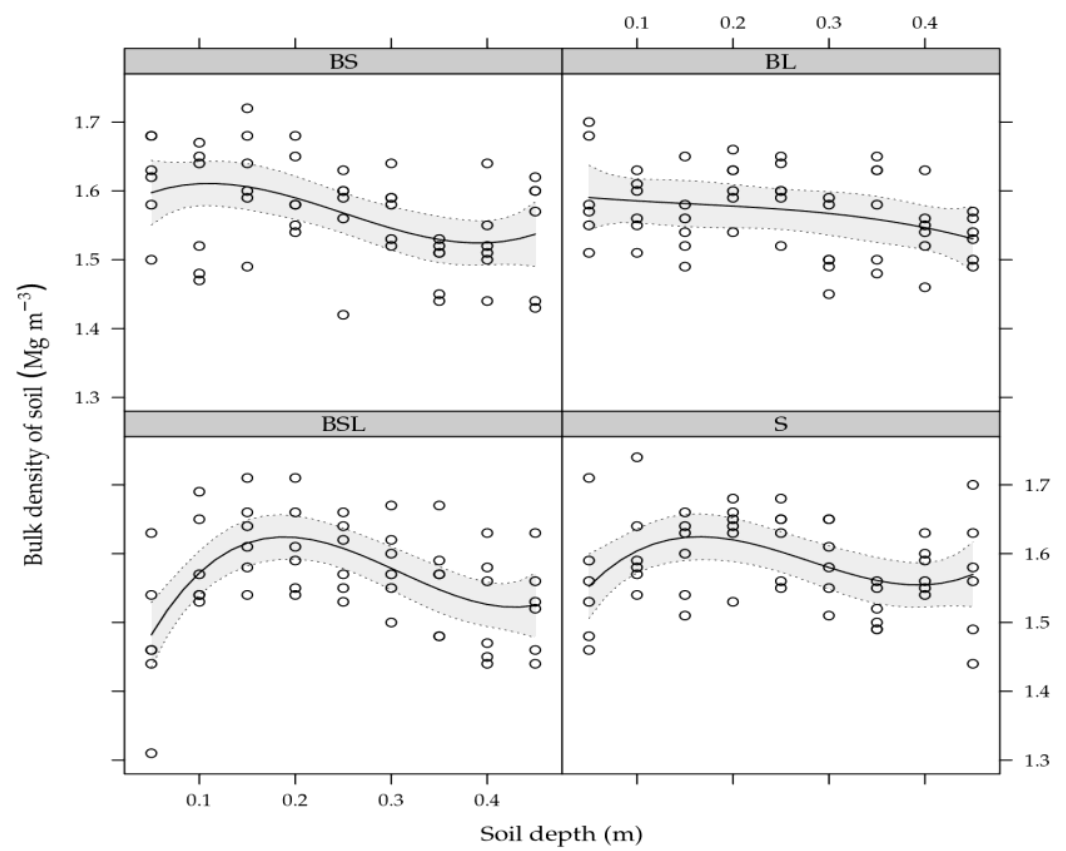

Figura 4. Valores para a densidade do solo $\left(\mathrm{Mg} \mathrm{m}^{-3}\right)$ em função da profundidade do solo (m) em cada nível de manejo. A linha que expressa o ajuste do modelo está acompanhada das bandas de confiança (95\%).

Figure 4. Soil density $\left(\mathrm{Mg} \mathrm{m}^{-3}\right)$ as a function of soil depth (m) at each management level. The line that expresses the fit of the model is accompanied by the confidence bands (95\%).

Significant effects for the BS and BL management layers concerning soil resistance to penetration were observed (Figure 5). The lowest soil resistance was observed in the subsurface layers, associated to lower soil density. No statistically significant differences for the evaluated depths were noted for the BSL and S managements.

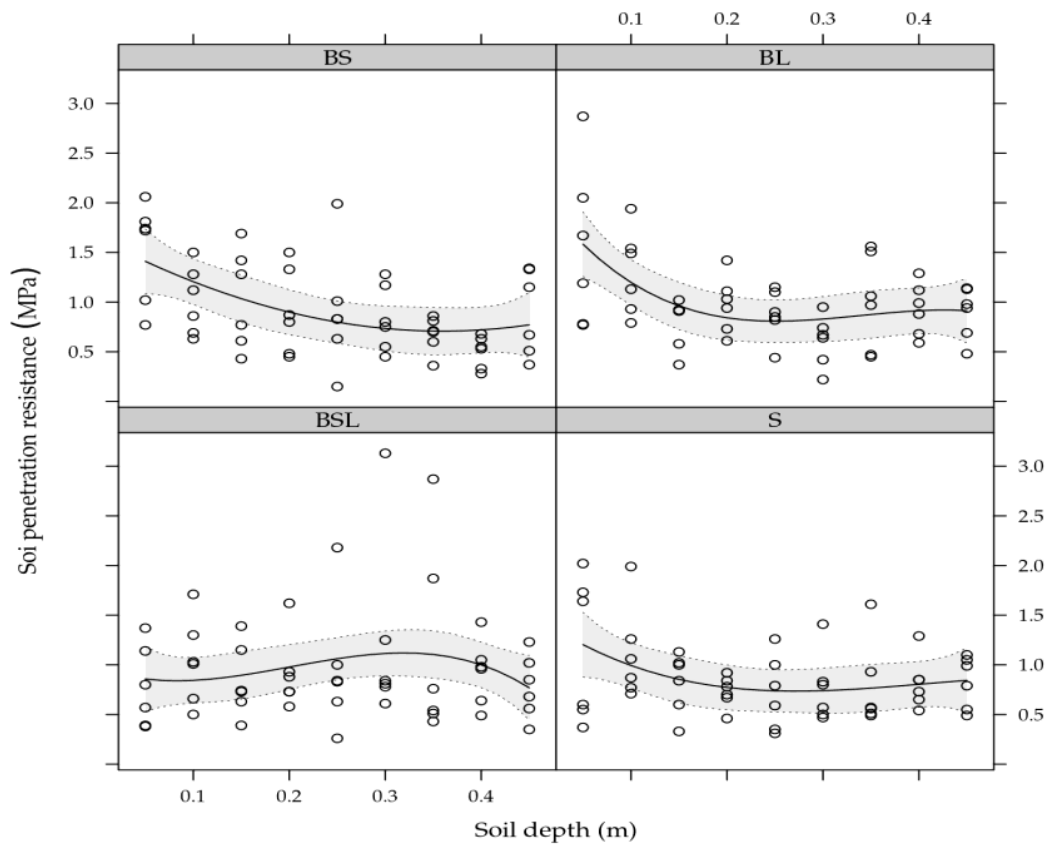

FLORESTA, Curitiba, PR, v. 50, n. 4, p. 1679 - 1688, out/dez 2020.

Florentim, E. T. S. et.al.

ISSN eletrônico 1982-4688

DOI: 10.5380/rf.v50 i4. 57466 
Figura 5. Resistência do solo à penetração (MPa) em função da profundidade do solo $(\mathrm{m})$ em cada nível de manejo. A linha que expressa o ajuste do modelo está acompanhada das bandas de confiança (95\%).

Figure 5. Soil penetration resistance (MPa) as a function of soil depth (m) at each management level. The line that expresses the fit of the model is accompanied by the confidence bands $(95 \%)$.

\section{DISCUSSION}

The adoption of an economically profitable and sustainable system aiming to minimize eucalyptus forest establishment costs by using less implements, as well aiming to reduce soil revolving and increase soil protection by using cover plants, leads to positive results for both physical soil quality and crop development (SILVA et al., 2011).

The adoption of conservationist soil management systems compared to conventional systems aims to minimize soil disturbances and maintain greater surface protection through cover crops comprising cultural residues, which favor a continuous supply of organic carbon, paramount in maintaining adequate quality soil structure (STEFANOSKI et al., 2013). In contrast, soils under conventional management systems are prone to greater compaction, due to soil structure degradation and decreased microbial activity, leading to increased soil density and decreased total porosity (BERTOL et al., 2019).

The total porosity results reported herein did not differ significantly for either management system of layer, with mean values $\left(0.37 \mathrm{~m}^{3} \mathrm{~m}^{-3}\right)$ within the ideal range, reported as 0.3 to $0.6 \mathrm{~m}^{3} \mathrm{~m}^{-3}$ (BERTOL et al., 2019).

Macroporosity values in all studied management systems and layers were above the critical limit of $0.10 \mathrm{~m}^{3}$ $\mathrm{m}^{-3}$, similar to the findings reported by Silva et al., (2011) and Rocha et al., (2015), who demonstrated that macroporosity values above this limit indicate favorable plant growth and root development conditions.

The results of the present study are in contrast to those reported by Souza et al. (2016) who noticed differences between soil depths in eucalyptus cultivation. In addition, the aforementioned authors observed macroporosity changes in native forests layers, but only below $0.40 \mathrm{~m}$, whereas differences in eucalyptus crops were observed at the superficial $0.00-0.20$ m layer.

The density results ranging from $1.44 \mathrm{Mg} \mathrm{m}^{-3}$ to $1.66 \mathrm{Mg} \mathrm{m}^{-3}$ reported by Rosa et al. (2018), evaluated after one year of eucalyptus sowing, are similar to the values reported herein, and lower than the critical or restrictive levels proposed by Reichert et al. (2007) of .91, 1.93 and $1.94 \mathrm{Mg} \mathrm{m}^{-3}$ for the $0.0-0.10 \mathrm{~m}, 0.10-0.20 \mathrm{~m}$ and $0.20-0.40 \mathrm{~m}$ layers, respectively.

According to Reinert et al. (2008), lower densities in top soil layers are associated to higher amounts of roots originating from the main crop and/or cover crops, which contribute to increasing organic matter deposition, improved soil physical properties and decreased soil density.

Soil resistance to penetration for all studied depths and management systems ranged from 0.58 to $1.5 \mathrm{MPa}$, below the established critical value of $2 \mathrm{Mpa}$, indicating favorable root development conditions (GONÇALVES et al., 2017). Concerning all management systems, a lack of statistically significant differences for the evaluated depths was observed only for the BSL management.

The establishment of the eucalyptus crop leads to positive soil physical attributes, indicating adequate eucalyptus development values. In addition, a forest effect concerning physical soil attribute standardization after different soil preparation and/or implantation interventions was observed, similarly to that reported by Rocha et al. (2015), with two years noted as enough time to obtain soil uniformity.

\section{CONCLUSIONS}

- No management effects on soil attributes were observed two years after eucalyptus planting.

- An effect of management:spline bases (layer) interaction was observed for soil density and resistance to penetration.

- The soil attribute values reported herein are within an adequate range for eucalyptus development, indicating a positive effect of this culture on physical soil attributes.

- Eucalyptus planting over a pasture area with no soil revolving thoughout the total area is a viable conservationist alternative for the western Mato Grosso region.

FLORESTA, Curitiba, PR, v. 50, n. 4, p. 1679 - 1688, out/dez 2020.

Florentim, E. T. S. et.al.

ISSN eletrônico 1982-4688 


\section{REFERENCES}

BAPTISTA, J.; LEVIEN, R. Métodos de preparo de solo e sua influência na erosão hídrica e no acúmulo de biomassa da parte aérea de Eucalyptus saligna em um Cambissolo Háplico da depressão central do Rio Grande do Sul. Revista Árvore, Viçosa, vol. 34, n. 4, p. 567 - 575, 2010.

BERTOL, I.; MARIA, I. C.; SOUZA, L. S. Manejo e conservação do solo e da água. Viçosa, MG, p.1355, 2019.

BORDRON, B.; ROBIN, A.; OLIVEIRA, I.R.; GUILLEMOT, J.; LACLAU, J.P.; JOURDAN, C.; NOUVELLON, Y.; ABREU-JUNIOR, C.H.; TRIVELIN, P.C.O.; GONÇALVES, J.L.M.; PLASSARD, C.; BOUILLET, J.P. Fertilization increases the functional specialization of fine roots in deep soil layers for young Eucalyptus grandis trees. Forest Ecology and Management, vol. 431, p. 6-16, 2019.

FERREIRA, D. H. A.; LELES, P. S. S.; NETO, S. N. O.; PAULA, T. R.; COUTINHO, R. P.; SILVA, R. L. Crescimento e produção de Eucalipto na região do médio Paraíba do Sul, RJ. Floram - Floresta e Ambiente, vol.24, Seropédica, 2017.

GHOSH, B. N.; MEENA, V. S.; SINGH, R. J.; ALAM, N. M.; PATRA, S.; BHATTACHARYYA, R.; SHARMA, N.M.; DADHWAL, K.S.; MISHRA, P.K. Effects of fertilization on soil aggregation, carbon distribution and carbon management index of maize-wheat rotation in the north-western Indian Himalayas. Ecological Indicators, vol. 105, p. 415-424, 2019.

GONÇALVES, S. B.; LOPES, E. S.; FIEDLER, N. C.; CAVALIERI-POLIZELI, K. M. V.; STAHL. J. Resistência do solo a penetração em diferentes profundidades de subsolagem. Nativa, Sinop, vol.5, n.3, p.224 - 229, 2017.

IBÁ - Industria Brasileira de Árvores, 2019. RELATÓRIO 2019. Brasília. Disponível em: https://iba.org/datafiles/publicacoes/relatorios/iba-relatorioanual2019.pdf

NEVES, S. M. A. S.; NUNES, M. C. M.; NEVES, R. J. Caracterização das condições climáticas de Cáceres/MT Brasil, no período de 1971 a 2009: subsídio às atividades agropecuárias e turísticas municipais. Boletim Goiano de Geografia. Goiânia, vol.31, n.2, p. 55 - 68, 2011.

NEVES, J.C.L; BARROS, N. F; NOVAIS, R. F; LEITE, R. A; ALVAREZ, V. V. H; SILVA, I. R. Monitoramento nutricional e recomendação de adubação. Apresentação no Encontro Nacional de Silvicultura. Curitiba, v.1, p. 5160, 2008

PINHEIRO, J.; BATES, D.; DEBROY, S.; SARKAR, D. R Core Team (2019). nlme: Linear and Nonlinear Mixed Effects Models. R package version 3.1-140, <URL: https://CRAN.R-project.org/package=nlme>.

REICHERT, J. M.; SUZUKI, L. E. A. S.; REINERT, D. J. Compactação do solo em sistemas agropecuários e florestais: identificação, efeitos, limites críticos e mitigação. Sociedade Brasileira de Ciência do Solo. Tópicos em Ciência do Solo. Viçosa, MG: SBCS, p. 1-48, 2007.

REINERT, D. J.; ALBUQUERQUE, J. A.; REICHERT, J. M.; AITA, C.; ANDRADA, M. M. C. Limites críticos de densidade do solo para o crescimento de raízes de plantas de cobertura em Argissolo vermelho. Revista Brasileira de Ciência do Solo, Viçosa, vol. 32, p.1805 - 1816, 2008.

ROCHA, S. P.; PREVEDELlO, J.; REINERT, D. J.; FLEIG, F. D.; VOGELMANN, E. S.; SOARES, J. C. W.; HEINZ, B. B. Propriedades físicas do solo e crescimento de eucalipto implantado em diferentes métodos de preparo do solo. Scientia Forestalis, vol. 43, n. 108, p. 965 - 977, 2015.

ROSA, S. F.; REINERT, D. J.; REICHERT, J. M.; FLEIG, F. D.; RODRIGUES, M. F.; GELAIN, N. S. Propriedades físicas e químicas de um argissolo sob cultivo de Eucalyptus dunnii Maiden na pampa gaúcha. Ciência Florestal, Santa Maria, vol. 28, n. 2, p. 580-590, 2018.

SANTOS, G. A.; RESENDE, M. D. V.; SILVA, L. D.; HIGA, A.; ASSIS, T. F. Interação genótipos x ambientes para produtividade de clones de Eucalyptus L'Hér. no estado do Rio Grande Do Sul. Revista Árvore, Viçosa, vol. 39, n.1, p. $81-91,2015$.

FLORESTA, Curitiba, PR, v. 50, n. 4, p. 1679 - 1688, out/dez 2020.

Florentim, E. T. S. et.al.

ISSN eletrônico 1982-4688

DOI: $10.5380 /$ rf.v50 i4. 57466 
SILVA, M. A. D.; SILVA, M. L. N.; CURI, N.; AVANZI, J. C.; LEITE, F. P. Sistemas de manejo em plantios florestais de eucalipto e perdas de solo e água na região do Vale do Rio Doce, MG. Ciência Florestal, vol.21, n. 4, p.765-776, 2011.

SILVA, D. A.; SOUZA, L. C. F.; VITORINO, A. C. T.; GONÇALVES, M. C. Aporte de fitomassa pelas sucessões de culturas e sua influência em atributos físicos do solo no sistema plantio direto. Bragantia, Campinas, vol. 70, n. 1, p.147-156, 2011.

SOUZA, J. M. Propriedades físicas do solo de áreas cultivadas com pastagem e eucalipto convertidas de área da Floresta Atlântica. Scientia Agraria Paranaensis. Marechal Cândido Rondon, vol. 15, n. 4, p. 487 - 492, 2016.

STEFANOSKI, D.C.; SANTOS, G.G.; MARCHÃO, R.L.; PETTER, F.A.; PACHECO, L.P. Uso e manejo do solo e seus impactos sobre a qualidade física. Revista Brasileira Engenharia Agrícola e Ambiental, vol.17, n.12, p.13011309, 2013.

TEIXEIRA, P. C.; DONAGEMMA, G. K.; FONTANA, A.; TEIXEIRA, W. G. Manual de Métodos de Análise de Solo. Embrapa, ed. 3, revista ampliada, Brasília, 2017.

WENDLING, B.; VINHAL-FREITAS, I. C.; OLIVEIRA, R. C.; BABATA, M. M.; BORGES, E. N. Densidade, agregação e porosidade do solo em áreas de conversão do cerrado em floresta de pinus, pastagem e plantio direto. Bioscience Journal, Uberlândia, vol. 28, n. 1, p. 256-265, 2012. 